\title{
Consensus
}

Volume 31

Issue 2 Faith, Freedom, and the Academy

Article 3

$11-1-2006$

\section{Theological knowledge and the knowledges of the university: beginning explorations}

Stanley Hauerwas

Follow this and additional works at: http://scholars.wlu.ca/consensus

\section{Recommended Citation}

Hauerwas, Stanley (2006) "Theological knowledge and the knowledges of the university: beginning explorations ," Consensus: Vol. 31 : Iss. 2 , Article 3.

Available at: http://scholars.wlu.ca/consensus/vol31/iss2/3 


\title{
Theological Knowledge and the Knowledges of the University: Beginning Explorations
}

\author{
Stanley Hauerwas \\ Gilbert T. Rowe Professor of Theological Ethics \\ Duke Divinity School, Durham, North Carolina
}

\section{Beginning Explorations}

It is no secret that theology is no longer considered a necessary subject in the modern university. I am getting old, but I have given myself the task before I die to understand better why this is the case and what, if anything, might be said that could help those that assume that theology is not to be part of modern university curricula to think again. Yet I have to admit that I am unsure how to pursue this subject, beset as it is by historical, political, and intellectual developments not easily separated. So the subtitle of this paper, "Beginning Explorations," not only is an attempt to be truthful about the status of the claims I make in this paper, but also is a call for help. I would and will welcome those who can help me ask the right questions or even know where to begin thinking about where to begin.

I have begun to explore these questions in several papers over the past few years. For example, I have written a paper on Luigi Giussani's book, The Risk of Education, in which I try to draw out the implications for the university of Giussani's claim that:

The Christian fact is permanent throughout history. It has a structure that nothing can change because it is a definitive event. Nevertheless, the Christian who lives out this event, in dealing with the cultural, social, and political conditions of his times - unless he lacks intelligence or is slothful - cannot help but judge the prevailing ideas and structures from the point of view of his lived faith. As a result, the desire to create an alternative culture and alternative structures is unavoidable. ${ }^{1}$

If Giussani is right, and I certainly think he is, I argue that Christianity may well produce knowledges that are different than those represented in the modern university. In a sermon entitled "On Milk and Jesus," celebrating the installation of Dr. Gerald Gerbrandt 
as the first President of the Canadian Mennonite University, I even suggest that if Christian universities are faithful to the material practices that make Christians Christian, it is not unreasonable to think that the way knowledges are shaped in Christian universities knowledges such as physics and agriculture - may appear quite differently than in other universities. ${ }^{2}$

I have also argued in a paper entitled, "Pro Ecclesia, Pro Texana: Schooling the Heart in the Heart of Texas," that the current enthusiasm to think what makes a university Christian is a concern for the teaching of "ethics" is a mistake. The "ethics" that is inevitably taught in the name of making the university morally responsible, I argue, cannot help but underwrite the students' presumption that when everything is said and done they have to make up their own minds. Moreover, to concentrate on "ethics" as the identifying mark of Christian education fails to note that the most important ethical formation of students in universities occurs in courses that allegedly have nothing to do with ethics. In each of these papers I argue that at least one of the problems facing any serious attempt at Christian higher education is an unwillingness to explore the tensions between what universities should be and the necessity to produce students who are good citizens in social orders that are allegedly democratic.

These papers do no more than set the stage for the issue I will try to address in this paper, namely, why it is assumed that theology is not a proper subject in the modern university. Why is it assumed that the kind of knowledge theology represents is in some fashion deficient when compared to other academic subjects? Of course, some may object that theology can be taught in the modern university as long as you assume theology names no more than a report on what was once believed or still believed by Christians. Such a view, however, makes the issue far too easy. Theology proper may involve such reports, but theology as a discipline is a constructive and normative mode of reflection on how and what Christians believe about the way things are in the light of our conviction that the way things are has been created by God. ${ }^{3}$

It is my conviction that until we can make some headway on these issues, all the talk about how the Christian university might be different than other universities is just that: it is just talk or, put more negatively, such talk is ideological. Yet given the complex reality of 
the contemporary university, Christian or non-Christian, it is not easy to know how the question or questions involving why or how theological knowledge may or may not be a legitimate subject in the university can be pursued. If, for example, most academics think there is no problem for departments of economics and schools of business to presume the normative status of the capitalist order, that is, capitalism can be advocated between consenting adults, why is there such a problem with theology? I assume the answers to the question why theology is excluded from the university differ from one institution to another. But in order to make the question concrete, I think a speech by the President of Yale, Richard Levin, nicely exemplifies some of the major reasons theology is thought to be at best not necessary for educating students and at worst a subject that cannot pass the epistemological standards necessary to be an academic subject.

\section{An Exhibit of the Problem}

Soon after becoming President of Yale, Richard Levin addressed the incoming class of 1993. Since this was the first address President Levin made as President, much thought obviously went into what he had to say. The address was entitled, "The Capacity for Independent Thought" and was reprinted in the Yale University Magazine. President Levin begins by noting it is important to make clear what those newly entering Yale as well as their parents are "buying for all that money." "According to Levin they are buying a liberal education that is different from a professional education or vocational training.

Some, he notes, define liberal education in terms of a curriculum associated with great works of literature, philosophy, and history. Others, following Cardinal Newman, argue that liberal education is an end in itself directed to no purpose other than the free exercise of the mind. Levin observes, however, that these views need not be in conflict and in fact a report by the Yale College faculty in 1827, underwritten by the then President of Yale, Jeremiah Day, argued that the development of qualities of mind and mastery of certain specific content were inseparable. According to Levin, the faculty recognized that the corpus of knowledge appropriate to liberal education was not immutable. "As knowledge varies, education should vary with it."5

Levin claims that as observers and forecasters of the development of the liberal curriculum in America the authors of the 
1827 Yale report were quite accurate. The curriculum has changed but the university is still committed to providing a liberal education. In particular Levin observes, "We no longer consider rhetoric and theology, for example, to be indispensable subjects." Such subjects cannot be at the heart of a liberal education according to Levin because the essence of such an education is "to develop the freedom to think critically and independently, to cultivate one's mind to its fullest potential, to liberate oneself from prejudice, superstition, and dogma."

Science and mathematics are, therefore, crucial for the development of such a mind. In pure mathematics and theoretical physics, for example, one learns how to reason deductively from clearly defined premises. In the experimental sciences one learns the method of induction, how to make proper inferences from evidence. Similarly, the great works of Western Philosophy provide examples of how the mind liberates itself from prejudice by the rigorous application of reason to questions of how we know and how we act.

Levin argues what is read does matter, but less attention should be paid to race, ethnicity, and gender of the authors read, and more to how they confront what it means to be human.

Yet whatever the content of the curriculum might be, Levin argues that it is not the role of the university to teach these freshmen what to think but rather how to think. In order to drive this point home, Levin quotes Thomas Jefferson's advice to his nephew Peter Carr in 1787: "Fix reason firmly in her seat, and call to her tribunal every fact, every opinion .... Lay aside all prejudice on both sides, and neither believe nor reject anything, because any other persons ... have rejected it or believed it. Your own reason is the only oracle given you by heaven, and you are answerable, not for the rightness, but uprightness of the decision." Levin comments that such an endorsement of reason and independent critical thinking has not lost its importance. "The university remains committed to these values of the Enlightenment."

Levin observes that the argument he has made against "useful" knowledge allies him with Cardinal Newman, who rejected utilitarian arguments for support of higher education. But Levin also notes that Newman "with some irony" noted that an education aimed solely at developing the capacity to reason can be defended on utilitarian grounds because it produces good citizens. Such an education does so 
because a man so trained has a clear and conscious view of his own opinions and judgments, "a truth in developing them, an eloquence in expressing them, and a force in expressing them. It teaches him to see things as they are, to go right to the point, to disentangle a skein of thought, to detect what is sophistical, and discard what is irrelevant. It prepares him to fill any post with credit, and to master any subject with facility."

According to Levin, liberal education is, therefore, a crucial source for "the preservation of individual freedom and democracy." Democracies depend on citizens who have been liberally educated, that is, who have the capacity for reason, reflection, and critical judgment. Citizens so educated are the most reliable source of resistance to forces of prejudice and intolerance that always threaten to undermine free inquiry and free expression.

I have taken the time to present President Levin's account of liberal education not because I think it peculiarly perverse, but because it so nicely articulates the general assumptions that are assumed as a given in American education. Of course we may wonder how anyone could become president of a major American institution who assumes that Thomas Jefferson and Cardinal Newman can be in agreement about anything. But perhaps President Levin should not be held accountable. He is an economist. But surely his speech writer should have known better.

\section{The Incoherence of the University}

More troubling than the sources Levin uses to support his views, however, is how President Levin's speech belies the university he administers. I am not suggesting President Levin is consciously duplicitous in his advocacy of a liberal education. Rather I am suggesting that quite understandably he is unable to give a coherent account of the diverse reality that is the modern university which I assume Yale represents. For Yale University, like almost any large university in America, is constituted by utilitarian and research endeavors that are not consistent with President Levin's advocacy of a liberal education. The freshmen, moreover, will discover in their first week of classes that President Levin's speech has little to do with the reality of Yale.

In his extraordinary account of the crucial period from 1865 to 1910 of the American university, Laurence Veysey helps us 
understand how the universities we now inhabit came to be. Veysey notes that the early justification of the universities - committed to defend what Protestants understood as orthodoxy - as the place where the mental and moral faculties of the students were disciplined by rigorous study of ancient languages was soon defeated. The defeat of this mode of education was not the result of a clear alternative educational theory or practice, but rather was more a response to the need for the university to justify itself to a quite different social order than the one that gave birth to early Harvard and Yale.

According to Veysey, after the Civil War almost every significant change in higher education lay "in the direction of concessions to the utilitarian type of demand for reform." 6 Students were to be educated for "real life," which meant they were to be made citizens of a democratic nation by being trained in the university with the skills befitting their vocational ambitions. Veysey notes that the appeal to democracy was as ubiquitous as it was vague, ${ }^{7}$ but such an appeal served to justify the acceptance by universities of subjects that had once been excluded. The founding of Cornell gave institutional form to this kind of university, but the appeal to democracy was also shaping developments at Harvard under President Eliot. ${ }^{8}$

The development of the "serviceable university" resulted in a transformation of the curriculum by the beginning of a variety of new departments of learning. Departments of education, domestic science, business administration, sanitary science, physical education and engineering became part of the accepted curriculum of the university. David Starr Jordan, the president of Cornell, Indiana, and Stanford, declared in 1899 that "it is not for the university to decide on the relative values of knowledge. Each man makes his own market, controlled by his own standards. It is for the university to see that all standards are honest, that all work is genuine." 9

At the same time as utilitarian justifications were shaping the university, the influence of German universities in their stress on research was also having an effect on the American university. Though often associated with the founding of Johns Hopkins University, Veysey argues, the ideal of the "pure scientist" became widespread throughout American institutions. The emphasis on science for science's sake in an interesting way resulted in an increasing specialization of knowledge shared with the movement toward practicality. ${ }^{10}$ In fact, however, the assumptions of the 
"intense seeker after new knowledge" took on the characteristics once associated with religion. Veysey even suggests these determined researchers were the new monks in service to an ideal of the university that was increasingly seen as an alternative to the religious past. ${ }^{11}$

Yet the influence of Germany was to be balanced by the continuing appeal of Oxford and Cambridge. So for many the university was still considered the crucial institution for the liberalizing of culture through the training of gentlemen. ${ }^{12}$ It was assumed that the training of the cultured personality was to be done primarily through what we now call the humanities. ${ }^{13}$ The commitment to the humanities in the name of educating the "well rounded individual" was often associated with colleges, but was also very influential at Yale and Princeton. However, this commitment to scholarship as a formation of an elite (which meant it was sometimes seen to be in tension with democracy) could be found in figures such as the Harvard Philosopher, George Santayana. Santayana put the matter this way: "There are always a few men whose main interest is to note the aspects of things in an artistic or philosophical way. They are rather useless individuals, but as I happen to belong to the class, I think them much superior to the rest of mankind." 14

For anyone associated with the university it is not hard to see the continuing influence of these developments Veysey locates in the antebellum university in America. Yet as helpful as Veysey's description of these various emphases may be, I think even more important is his attention to the development of the institutionalization of the university from 1890 to 1910 . By 1890 the university was assumed to be part of the American landscape. In short it had become a success. ${ }^{15}$ The success meant that however the faculty may have understand the work of the university, the main character of the university was determined by the emerging bureaucratic structure. The university was now an institution identified by "the administration": characterized by a hierarchy comprised of trustees, president, deans, department chairmen, and finally the faculty. ${ }^{16}$ No matter what the faculty thought about educational alternatives, the administrator was bound to be a diplomat and politician if he was to serve the institution. Holders of such offices thrive on compromise, wanting all sorts of diverse people to go away pleased. ${ }^{17}$ Veysey observes: 
Here, then, was a major and controversial new force in American academic life. In response to what conditions had it appeared? The most important answer lies with the institution. Both intellectually and in terms of structure, the American university was becoming too diverse easily to define - or to control. The adherence of academic leaders to varying educational philosophies, the emergence of crystallized departments of learning, and the presence of larger numbers of students all contributed to this result. Often an undergraduate college basically English in conception was wedded, by loose financial ties, to a Germanic graduate school. To European eyes an American institution such as Harvard might seem "a chaos." No longer did any over-all intellectual formula exist to counter (or to cloak) such fragmentation; neither the Christian religion in any of its varieties, nor positive science, nor humane culture proved selfevidently capable of making sense out of the entire range of knowledge and opinion. As long as argument in these terms was possible, the university could mean no one thing. Santayana despairingly commented: "Each man knows the value of his work ... but he feels also the relativity of this work and of its value without being able to survey the whole organism of human interests and adjust himself confidently to the universal life."18

I think that helps explain why President Levin's address is such an incoherent but interesting document. Levin at once privileges the sciences to supply both inductive and deductive forms of rationality in order to defend a liberal understanding of the purpose of the university. He seems to disavow all utilitarian justifications other than that training in the sciences and reading the great works of Western philosophy will produce people capable of sustaining democracy. As I suggested above, however, such an account fails to do justice to the utilitarian justification of many of the disciplines, including Levin's discipline of economics, so characteristic of the modern university and no doubt true of Yale. It is equally the case that the sciences do not understand themselves to be "pure," but rather represent research agenda funded by the NSF and NIH and justified by the promise of future developments. ${ }^{19}$

Perhaps even more troubling, Levin seems to have no understanding of the problematic character of his understanding of rationality. He seems to assume that the "prejudice, superstition, and dogma" from which we are to be liberated by reason has been decisively called into question by intellectual developments of the university. ${ }^{20}$ From such a perspective his dismissal of theology, a 
dismissal no doubt he thinks justified by his assumptions about rationality, is quite simply arbitrary. ${ }^{21}$ One suspects such dismissals of theology have more to do with the politics of liberal social orders than whether theology passes muster as a knowledge of the university. The determination of liberal societies to keep religious convictions private is one reason, if not the most important reason, theology is not thought to be appropriate in university curricula. Such curricula increasingly seem determined to avoid teaching any subject that is considered "controversial" because such subjects do not represent the kind of knowledge necessary to secure cooperation between individuals in liberal societies.

If I am right to describe Levin's address as a representative of the "incoherence" of the American university, one might think such an incoherence to be an opportunity for the reintroduction of theology as a subject in the modern university, ${ }^{22}$ a subject that will probably be seen as one of the "methods" characteristic of religious studies departments. Of course, to have theology so located may not be an advantage, as few departments in the modern university are as controverted as "religious studies." 23 Indeed I think it is quite telling that departments of history and religious studies often are the last representatives of modernist presumptions about objectivity and rationality.

John Milbank observes that the condition in which the modern university finds itself can provide what he characterizes as a cynical reason for theology in the university. That cynical reason is that:

utter incoherence and lack of ability to withstand the critical trial of reason does not matter so long as one can come up with cash and customers; in our postmodern era the "free, rational inquiry" of the Enlightenment which could reveal only formal truths as objectively real, thus handing over the whole realm of the substantive to the play of agnostic forces, has itself been inevitably invaded by such forces, since form feeds only on the substantive, and never perfectly inhabits its own purity. Enlightenment, therefore, is bound to evolve into the postmodern mixture of the purest, most unbounded and therefore most rigorous logic, plus the most untrammelled sway of vanity and fashion. In many ways a "religious studies department" is well adapted to our era. But we should be warned: the point of fashion is to change, and religious constituencies may well yet further wither away, or more probably mutate and take their custom elsewhere, far away from universities (or what in the future will remain of them). ${ }^{24}$ 


\section{Theology and the University: Can Newman Help?}

I think Milbank is right to warn us against using the incoherence of the modern university to secure a place for theology. I have some sympathy, moreover, for his claim that at least one of the reasons that the university finds itself in disarray is because it has abandoned the theological task of studying that which is inimitably real. In his essay, "The Conflict of the Faculties: Theology and the Economy of the Sciences," with his customary audacity Milbank argues, contra Kant, that theology is now the only discipline capable of reclaiming the purpose of the university. ${ }^{25}$ It is so because truth for theology is the adequation of knowledge with the real, but only God is the entirely real reality who is infinitely actual and infinitely knowing. ${ }^{26}$ It is not, therefore, a question of the legitimacy of theology in the university, but rather unless all the "other disciplines are (at least implicitly) ordered to theology (assuming that this means participation in God's self-knowledge - as in the Augustinian tradition) they are objectively and demonstrably null and void, altogether lacking in truth, which to have any meaning must involve some sort of adequation (for mere 'coherence' can only concern the coherence of convention or appearances)." 27

I confess I am tempted to side with Milbank if for no other reason than that his position is so offensive. Moreover, that such a position does not have a "snowball's chance in hell" of being realized in the university as we know it makes it all the more attractive. But we must still ask if Milbank's account of theology is true to the character of the church's understanding of the theological task. I wonder, for example, if Newman were alive today would he be saying something like Milbank? In order to answer that question I think it worth our while to look at Newman's understanding of theology and the role of theology in the university.

Newman's The Idea of a University has often been used as a defense of the "liberal arts college." No doubt Newman's insistence that the university is primarily about teaching not about creating new knowledge, though he was not against the pursuit of such knowledge elsewhere, is one of the reasons his book has been so appealing to those committed to passing on to future generations the "great texts." 28 I certainly do not mean to call into question many that have used Newman to defend "the tradition," but I think such readings can fail to do justice to the subtle account Newman gives of knowledge and, in particular, the knowledge of theology. 
For example, the claim with which Newman begins The Idea of a University, that is, that the university is "a place of teaching universal knowledge," is often interpreted in the modernist mode that makes Newman an advocate of knowledge as an end in itself. ${ }^{29}$ It is certainly true that Newman argued that "liberal knowledge" is that which "stands on its own pretensions, which is independent of sequel, expects no complement, refuses to be informed (as it is called) by any end, or absorbed into any art, in order duly to present itself to our contemplation." 30 I do not think, however, that Newman is commending art for art's sake or knowledge as an end in itself; for the crucial word is "contemplation," and Newman, being the good Augustinian that he was, knows that only God can be so contemplated. ${ }^{31}$

Levin-like appeals to Newman in support of the liberal notion that the knowledges that constitute the university have no "use" fail to ask what Newman means by "universal knowledge." By "universal" Newman did not mean that the knowledges that constitute liberal learning cannot be justified by their utility, but rather that all knowledge was interconnected because the "universe in its length and breadth is so intimately knit together." 32 To be educated is not to be well read or to know a great deal about this or that subject. Rather, it is the

only true enlargement of mind which is the power of viewing many things at once as one whole, of referring them severally to their true place in the universal system, or understanding their respective values, and determining their mutual dependence. Thus is that form of Universal Knowledge set up in the individual intellect, and constitutes its perfection. Possessed of this real illumination, the mind never views any part of the extended subject-matter of Knowledge without recollecting that it is but a part, or without the associations which spring from this recollection. It makes every thing in some sort lead to every thing else; it would communicate the image of the whole to every separate portion, till that whole becomes in imagination like a spirit, every where pervading and penetrating its component parts, and giving them one definite meaning. ${ }^{33}$

Philosophy, not theology, Newman believes to be the discipline that is distinct from all the sciences, that is, "in some sense" philosophy is "a science of sciences." Newman assumes that the university will be constituted by many subjects and no one person will be capable of pursuing them all. ${ }^{34} \mathrm{~A}$ division of labor is 
necessary to insure the perfection of every art. Newman, for example, thinks attention should be given in the university to how wealth is produced. Therefore the study of Political Economy is to be expected. ${ }^{35}$ But philosophy is that "habit of mind" in which "the comprehension of the bearings of one science on another, and the use of each to each, and the location and limitation and adjustment and due appreciation of them all" is undertaken. Gerard Loughlin notes that for Newman, philosophy "is not so much a body of knowledge distinct from the other sciences, as the cast of mind by which those sciences are apprehended and thus united. It is 'an intellectual ... grasp of many things brought together in one.' It is not the unity of a general theory of everything, but of a community. Indeed, it is the university as such, in its universal scope and idea." 36

The significance of philosophy for Newman is nowhere more evident than in his claim that "university teaching without theology is simply unphilosophical." Newman argues that theology, that science of God by which "the truths we know about God are put into a system, has a least as good a right to claim a place there as Astronomy." "37 Note he does not make a theological argument for the inclusion of theology in the university, but rather argues that given that the object of knowledge is truth, then theology - which is a knowledge - cannot be excluded from the university. Accordingly,

if the various branches of knowledge, which are the matter of teaching in a University, so hang together, that none can be neglected without prejudice to the perfection of the rest, and if Theology be a branch of knowledge, of wide reception, of philosophical structure, of unutterable importance, and of supreme influence, to what conclusions are we brought from these two premises but this? that to withdraw Theology from the public schools is to impair the completeness and to invalidate the truthworthiness of all that is actually taught in them. ${ }^{38}$

The other sciences, therefore, need theology. In order to have possession of the truth of the various sciences, we must have the "whole truth." Theology is not just another subject, but it is the condition of general knowledge. ${ }^{39}$ Such truth includes the "revealed truths" which enter into the provinces of science, philosophy, and literature. Every science is not equally affected by the omission of theology. Pure mathematics will not suffer at all, chemistry will feel the difference less than politics, politics less than history, ethics, or 
metaphysics. But just to the extent the various subjects are connected with each other, the exclusion of theology will have a deleterious effect. Newman observes, for example, that "under the shadow of the church" philosophy does service to the cause of morality, but "when it is strong enough to have a will of its own" then it is tempted to form system of ethics in a manner that serves the evils it should oppose. ${ }^{40}$

Moreover theology also needs the other sciences, ${ }^{41}$ thus the title of Discourse IV of The Idea of a University, the "Bearing of Other Branches of Knowledge on Theology." For Newman the Catholic faith is true which means the church has no stake in trying to make every subject matter "Christian." For a university, even secular universities that may not have theology represented, cannot exist external to the Catholic pale as long as the quest to discover the truth in the connections is not lost. ${ }^{42}$ Truth is truth. The Christian accepts truth where he or she finds it without feeling the need to claim possession of that truth. ${ }^{43}$ After all, the Christian believes that "all that is good, all that is true, all that is beautiful, all that is beneficent, be it great or small, be it perfect of fragmentary, natural as well as supernatural, moral as well as material, comes from Him."44

That the church feels no necessity to dominate the various sciences and literatures in the university does not mean that criticism cannot be made of science and literature. But such criticism is not about the work of science itself, but about theories and attitudes the scientist may have assumed that are not constitutive of the science. The problem is usually that a science tries to explain more than its method will allow. For example, if it is asserted that we are but products of an endless series of physical causes and effects, we have an indication something has seriously gone wrong with the science that makes such claims. ${ }^{45}$

The university, therefore, has a constitution and independence in relation to the church; but practically speaking the university cannot fulfill its task to teach "universal knowledge" without the church's assistance. The university cannot maintain its integrity without the church. For the university, like all creation, needs the gift that is superadded to its nature without which nature is incomplete. ${ }^{46}$ Or as Newman puts it in The Idea of a University, the university has the office of intellectual education which is a good not requiring the church, but the church is necessary to steady the university in the performance of that office. ${ }^{47}$ 
I cannot pretend that I have done justice to Newman's subtle and complex account of the university and, in particular, the role of theology in the university; for I think Newman provides a quite helpful set of suggestions for how Christians can have a constructive role vis-à-vis the universities in which we find ourselves. I suspect that Newman, like John Milbank, would find the arrogance and insularity of many of the disciplines that comprise the university theologically problematic. But Newman, rightly I think, does not ask the various disciplines to submit to theology. Rather Newman helps us see that our theological task is to help the various disciplines of the university explore their limits, possibilities, and connections to other subjects. I do not think Newman thinks that such an enterprise will result in a unified account of all that is. The results will always be subject to further questions. The task of theology is quite rightly to force the questions to be asked.

Of course the last sentence Newman would not have written. He argues it is the philosopher's role to raise if not to force questions concerning limits, possibilities, and connections between disciplines be asked. I have no reason to disagree with Newman about the role of philosophy. My hesitancy is that quite simply few philosophers now understand their task as Newman understood their task. The "professionalization" of philosophy is now a reality. Philosophers have become "experts." It, therefore, seems that the primary role of theologians vis-à-vis the universities is to ask that philosophers do the job they were set aside to do.

\section{A Concluding Unsatisfying Postscript}

Is that all there is? Surely you must think that there has to be a bigger pay-off than the conclusion that theology needs philosophy if we are to find our way back into the university. I certainly think more can and needs to be said, but I do not think the significance of Newman's case for the importance of philosophy should be underestimated. Of course far more important than philosophy regaining its role in the university is the role itself, namely, that we must somehow recover in the university what Newman called the "teaching of universal knowledge." Yet in the university as we know it no persons, disciplines, or place exists charged with the responsibility to try to make what connections may and may not be able to be made. Connections are often made informally, but that is usually a happy accident that is not assumed to set a precedent. 
In the light of the inability to make the kind of connections Newman thought the heart of the university, some think theology should assume that task. If theology would undertake the project of "pulling it all together," perhaps theology might be recognized as a legitimate knowledge of the university. I think, however, that would be a very unfortunate strategy. I do think theologians often exhibit a gregarious intellectual agenda that should commend their presence in the university. That theologians read more widely than many of our colleagues in other discipline is because we are in the happy position, as the bottom feeders in the university, of having to know what others are thinking though they do not have to know what we are thinking. That theologians find themselves in the position of Hegel's slave I take to be a very good thing.

I think, however, there is another more important reason that theology is committed to "making the connections." The knowledge that theology names is knowledge of God. Of course theologians soon discover that such a knowledge is primarily negative, that is, theology is the ongoing discipline to teach us that most of what we have to say about God is that we do not know how to talk about God. But even to know what we cannot say means the theologian cannot divorce what is known and not known about God from all that we know. Indeed that is why I think Newman is right to suggest that theology not only potentially has something to say to other disciplines; but just as important, theology in order to be theology has to learn from other disciplines. ${ }^{48}$

To be sure, therefore, theology certainly is a "field" in which nothing that is known is irrelevant for the work theology must do. Yet, as I suggested above, I do not think that means theology should try to establish its importance for the university by promising to be the subject that shows where everything "fits." Such an ambition would be foolhardy because we do not live in a time when it is obvious that all that we know in fact "fits." At best theologians, with the aid of the philosophers, need to help us understand why what we know is so often a jumble.

There is another reason, peculiar to my own theological convictions, that makes it unwise for theology to pretend to be the discipline that brings order to the disorder of the knowledges of the university. A project to try to pull it all together I fear could be a nostalgic attempt to reclaim the habits of Christendom. Christendom 
created the Christian university that made it seem natural that theology would be the supreme science just as the church was the supreme institution. I, of course, do think the church is that community that rightly commands our loyalty in a manner that relativizes all other loyalties. But the church does so because she can only rule as a servant. Accordingly theology is only a "queen" of the sciences if humility determines her work.

That is why I think the situation we confront concerning the role of theology in the curricula of universities is in many ways quite favorable to the task to which we are called as theologians. It is a good thing that theology bears the burden of proof before the epistemological conceits of the knowledges represented by the contemporary university. That challenge should not only make us more truthful and faithful theologians, but we might also discover different ways to think theologically because we cannot assume the way theology was once done is the way we must do theology. Of course theology should never be done to pass muster in the university. Theology must be done in a manner that glorifies God and serves God's people. It has always been my conviction that when theology is so done, those in the university will take notice because what we have to say is so interesting.

Moreover, as I suggested at the beginning of this paper, I think we may well discover that theology cannot be relegated to the theology or religious studies department. I appreciate Newman's contention that the secular sciences should be allowed to be secular. But I think if Christians learn to take intellectually seriously the practices that should and do constitute the church, they may well find that how we think about economics, biology, or physics is different than how those subjects are now structured in the university. I think that is particularly true given the intellectual paradigms that dominate fields like economics and political science. ${ }^{49}$ The problem, of course, is not the university or the subjects that constitute the university. The problem is with those like myself who identify ourselves as Christians. Namely the challenge is whether any of us live lives as Christians that are sufficient to force us to think differently about what is and is not done in the university.

I am convinced, however, that theology's becoming a subject in the modern university will not happen if Christians only take a negative view of the current university. I obviously think that the 
university as we know it is in deep trouble, but that does not mean we would be better off without the university. We need to remember that there is no the university, which means that every university will present a different challenge for the teaching of theology. In order that theology be recognized as a legitimate endeavor that every university should desire to have represented in the curriculum, theologians must do the work of theology without fear. For theology to be recognized as significant, theologians must have something of significance to say.

It is, moreover, hard to imagine that theologians do not have something interesting to say given the subject of our work. It is hard to make God boring or have little significance for the way we live and think. The challenge before us, therefore, is not really whether we can convince our colleagues in the rest of the university that theology matters. The challenge is whether we are capable of performing the work of theology with the joy and confidence the subject of theology requires. ${ }^{50}$

\section{Notes}

1 Stanley Hauerwas, "How Risky is the Risk of Higher Education?: Random Reflections from the American Context," Communio 30/1 (Spring, 2003), p. 79-94. The passage quoted is from Giussani's The Risk of Education (New York: Crossroads, 2001), p. 117.

2 "On Milk and Jesus" is included in my book, Disrupting Time: Sermons, Prayers, and Sundries (Eugene OR: Cascade Books, 2005).

3 I do not think theology is an activity peculiar to Christians. It is quite clear that many Jewish thinkers are theologians. I am sure Islamic thinkers often "do" theology. I identify theology with Christianity, because that is the theology I know. My hunch, however, is that the need for theology may be different for Jews, Muslims, and Christians. That is clearly a topic for another day and for someone far more learned than myself. David Burrell, C.S.C., has done the best work so far on this subject. See his Freedom and Creation (Notre Dame: University of Notre Dame, 1993).

4 I will not be able to give the page numbers of quotes from Levin's speech because they were cut off by the photocopier. The address, however, covered only three pages in the Yale Magazine.

5 Levin seems quite unaware that what the Yale Report of 1827 meant by "quality of mind" was quite different than what it meant by the turn of 
the century. In his The Emergence of the American University (Chicago: University of Chicago Press, 1965), Laurence Veysey notes that people like Noah Porter of Yale thought the task of the university was to discipline the mental and moral faculties by forcing the student to work hard in abstract subjects. Veysey quotes Frederick Jackson Turner of Wisconsin to illustrate this view: "The student who has acquired the habit of never letting go of a puzzling problem - say a rare Greek verb - until he has analyzed its every element, and understands every point in its etymology, has the habit of mind which will enable him to follow out a legal subtlety with the same accuracy." Levin does note that in contrast to in the 18th century the Yale faculty no longer considers the mandatory study of Greek and Latin to be necessary.

6 Veysey, p. 60.

7 Veysey (pp. 63-65) identifies at least seven different meanings of democracy as applied to the university: (l) equality of all fields of learning no matter how technical or novel, (2) equality of treatment of all students attending the university, (3) all those attending the university meant that all qualified should be admitted to the university, (4) those prepared by the university were well positioned for individual success, (5) the desire for a wide diffusion of knowledge throughout society, (6) the idea that the university should receive its direction directly from the non-academic mass of citizens, and (7) setting a high standard of individual morality.

8 Veysey (p. 94) reports that Eliot responded to a paper by President Hadley of Yale on the organization of the thirteenth-century university with his customary audacity: "The American university has nothing to learn from medieval universities, nor yet from those still in the medieval period."

9 Veysey, p. 114.

10 Veysey, p. 142.

11 Edward Shils observes that "In the allegedly practical and 'materialistic' American society of the period after the Civil War, there was still a deep piety that had ceased to be monopolized by the doctrines of ecclesiastical Christianity. The seriousness with which fundamental knowledge was pursued by universities aroused the admiration of those possessed by this enduring piety. By their concern with fundamental learning, the universities were able to become, in a sense, the heirs of the churches. More specialized, more practical institutions could claim neither that vital inheritance nor the consequent support of private patrons and state legislators." "The Order of Learning in the United States: The Ascendancy of the University," in The Organization of 
Knowledge in Modern America, edited by Alexander Oleson and John Voss (Baltimore: John Hopkins Press, 1976), p. 31.

12 Charles Johnson, a professor at Trinity College in North Carolina, identified in 1892 five elements he thought crucial to the development of literary taste: (1) an instinctive appreciation of vowel and consonant "sound-sequence," (2) perception of a word to its meaning, (3) the ability to recognize a thought system, (4) the perception of the delicate revelations of the author's personality that make some books good in the highest sense, and (5) to be able to see the embodiment of a vital and congruous character in fiction (Veysey, pp. 184f.).

13 It is a mistake, however, to think the description "humanities" describes a unified subject. Veysey notes by the end of the 1880s the humanists had split into two different groups. One camp identified by the term "culture" resisted tendencies toward specialization and scientistic justification. The other camp, influenced by German scholarship, advocated advanced research that required increasing specialization necessary to justify the scholarship associated with the Ph.D. Veysey notes that the former espoused values associated with the elites of the college-trained, though they distanced their defense of their subjects from the past association with Christian orthodoxy. Laurence Veysey, "The Plural Organized Worlds of the Humanities," in The Organization of Knowledge in Modern America, edited by Alexander Oleson and John Voss (Baltimore: John Hopkins Press, 1976), pp. 35f. In The Emergence of the American University Veysey observes the commitment to liberal learning often meant a downgrading of Christian theology. This did not mean that the proponents of culture were skeptics, but rather that religion was no longer a central focus for their academic outlook. He quotes John Bascom who announced in 1881 that "Religion is not so much the foundation of morals, as morals the foundation of religion." (p. 203)

14 Veysey, The Emergence of the American University, pp. $213 \mathrm{f}$.

15 Not to be missed, however, is the "success" of a university did not necessarily mean that the students in the universities shared the same commitments as their teachers. Veysey notes that few undergraduates desired to identify themselves with the work of the institution in any lasting sense. Undergraduates resembled a conscript army rather than a dedicated core of professionals. Veysey extends this metaphor by observing "from one point of view the university existed primarily to keep students in temporary custody amid surroundings which their parents approved." (Emergence, p. 269) Veysey claims that few students took up learning for the sake of learning which also helps account for the "spectacular" rise of athletics, and in particular football, as an (if not the most) important aspect of college life for undergraduates. 
16 Veysey, Emergence, pp. 302-311. That Veysey does not mention "provosts" only indicates he wrote in 1965.

17 Veysey, Emergence, p. 311.

18 Ibid.

19 I have served eight years (to be sure at different times) on the Duke University Appointment, Promotion, and Tenure Committee. This is an advisory committee to the Provost dealing with internal promotions to tenure as well as external appointments. It is surely an indication of the diverse character of the knowledges that constitute the contemporary university that those on the committee are not to judge "fields," but only the person's standing in their field. The "fields," moreover, become increasingly specialized in order to be able to claim that the person up for promotion or for external appointment is "the best in their field." It is quite common for chairmen of fields to come before the committee indicating they know quite little about a member of their department field.

20 Alasdair MacIntyre's work stands as the most decisive critique of Levin's assumption that reason qua reason is not only possible but necessarily liberating. Indeed, one of the important developments is the increasing recognition that the sciences are inadequately understood when they are divorced from their temporal and spacial contexts. For example, David Livingston has recently argued that there was a distinct regional pattern to the rise of scientific Europe which means it is appropriate to use geographical adjectives such as "English science," "French science," and "Russian science" (Putting Science in Its Place: Geographies of Scientific Knowledge [Chicago: University of Chicago Press, 2003], p. 15). Livingston does not deny that the modern invention of the laboratory was an attempt to create a "placeless" science, but he argues that even laboratory knowledge turns out to be local: thus the difficulty in reproducing results from different laboratories. Livingston argues that there is good reason for suspecting that the term "science" is an "imaginary unity masking the disparate kinds of activity that trade under that label." In his An Examined Faith: The Grace of Self-Doubt (Minneapolis: Fortress Press, 2004), James Gustafson provides a lovely account of the dissonance created by the diverse sciences and subjects an undergraduate might study and how that dissonance makes it difficult for such a student to maintain any strong theological convictions. Gustafson observes it is unfortunate that "undergraduate curricula seldom, if ever, provide an academic milieu in which students can deliberate about the dissonance even within the human sciences and humanities, not to mention theology, and weigh the alternatives to which they are exposed" (p. 32). 
21 Whether an account of the diverse forms of reasoning in the diverse subjects of the university is possible is not clear to me. By serving on the APT committee I have learned that different disciplines use particular words to describe good work done in that discipline. For example, in physics the best work is described as "elegant," which seems to mean the implications of the work may not be understood or the work itself may not be understood, but the mathematics has an undeniable beauty. Work in mathematics is sometimes described as elegant, but mathematicians usually describe the best work as "deep." Deep mathematics usually indicates math not well understood in the community of mathematics. Once what was "deep" is generally understood, it becomes applied mathematics. Work in biology is usually described as "interesting," which means the work helps me understand or "see" what I had not understood. The primary words used in the social sciences are "robust," "powerful," "important," and "useful." "Robust" usually means work that helps the social scientist explain wider implications other than the ones the work was initially designed to accomplish. In the humanities the work is described as "influential" which seems to indicate that the work has changed the minds of other scholars who know something about that subject. In some fields in the humanities, such as philosophy, the work can be described as representing a "powerful" argument. I often reflect that the word that should best describe theology is "faithful" which may well make theology closer to mathematics and physics than the social sciences. At least in mathematics and physics it is still assumed that such work is committed to truth.

22 Some may well think "incoherence" an inappropriate description of the American university. After all, how many institutions in our society are "coherent"? "Incoherent" could equally be a description about most churches. By using the description "incoherent," I mean to do no more than suggest that no one has the authority or the intellectual resources to say what the university is for or whom it serves. I assume that one can and should give several responses to the question what the university is for, but it is by no means clear how those responses can be consistent with one another. That is why Veysey's account of the development of the modern university is so important. He helps us see that you do not need to be able to provide a coherent account of the activity that should characterize what universities are about as long as the university can be "administered." For a set of essays that on the whole assume that universities are beyond any possibility of having a coherent account of their work see The Postmodern University?: Contested Visions of Higher Education and Society, edited by Anthony Smith and Frank Webster (Philadelphia: Open University Press, 2002). 
In his essay, "The Postmodern University," Peter Scott observes the natural starting point to begin to think about the current university is what characteristics knowledge may have in the world in which we find ourselves. But he observes that "characteristics" suggest regularity and that is exactly what knowledge in our time does not possess (p. 36). In such a world Zygmunt Bauman suggests that the authority that now characterizes the intellectual is not the Cartesian Cogito, but rather, "I am talked about, therefore I am" (pp. 21f.).

23 One can cite a burgeoning literature about whether any coherence can be made for religious studies, but that is a subject for another time. However, for a particularly honest and revealing article that concerns how difficult it is to separate teaching "about" a religion without being an advocate, see Martin Jaffee, "Personal Self-Disclosure, Religious Studies Pedagogy, and the Skeptical Mission of the Public University," Bulletin of the Council of Societies for the Study of Religion 33/2 (April 2004), 29-34. In his dissertation written at the University of Chicago, Uses of Religion: The Dual Role of College Religion Departments at Mid-Century (June, 2002), Robert Wilson-Black argues that the midcentury founders of religion programs were forced to create departments in the face of an inherent tension if not contradiction. "College administrators and many faculty and alumni leaders wanted religion courses to include Western moral and civic values. At the same time it was expected that, in such a department, students should come to identify religion as a viable academic subject outside of or in addition to advocacy for one particular religious perspective. The question for most of these founders eventually became this: How does one, or should one, extract oneself as a religion professor from the advocacy for a Christian religious life - which was expected to mediate the crises of Western civilization and higher education at that time - while establishing credibility among academic colleagues who looked askance at such advocacy? Establishing their programs from 1940 to 1951, many founders dealt with these contradictory demands by attempting to distinguish teaching a religion from other academic subjects like philosophy, from 'the church,' from 'sectarian theology,' from 'Christianity,' or from campus chapel programs. Their rhetoric, curricular reforms, and arguments for the uses of teaching religion encouraged a fragmented identity for religion departments, the residue of which remains to this day" (pp. 9f.).

24 John Milbank, "The Conflict of the Faculties: Theology and the Economy of the Sciences," in Faithfulness and Fortitude: In Conversation with the Theological Ethics of Stanley Hauerwas, edited by Mark Thiessen Nation and Samuel Wells (Edinburgh: T\&T Clark, 2000), p. 40. 
25 Milbank obviously titled his essay to remind readers of Kant's famous essay, The Conflict of the Faculties. Milbank did so because he is, of course, arguing the exact opposite of Kant's position. In The Conflict of the Faculties, Kant distinguished between the higher and lower faculties noting that law, medicine, and divinity are called the higher faculties because they exist in the university only because they are useful to government. The lower faculties are not constituted by teaching that is adopted by order of a superior, but are determined by free, that is, autonomous reason. Kant observes that most people are persuaded by the higher faculties because people want to be led, even duped. But Kant argues that for governments to place all authority in the higher faculties would invite anarchy. So government has a stake in the truths of the higher faculty being subject to the lower faculty in order to assure that any historical claims have a rational origin. Kant argued that Christianity is the most adequate form of rational religion, but the lower faculty must stand in judgment of exegesis. Kant also saw no reason to assume that the doctrine of the Trinity, "taken literally," should have any practical relevance. Kant is, therefore, led to the blunt claim - "it is superstition to hold that historical belief is a duty and essential to salvation." Immanuel Kant, The Conflict of the Faculties in Religion and Rational Theology, translated and edited by Allen Wood and George DiGiovanni (Cambridge: Cambridge University Press, 1996), pp. 238-338. The last quote is from p. 285.

26 Milbank, p. 42. That theology is now done primarily in seminaries is part of the problem. Theology as the normative discipline of the church is rightly thought to be important for training people for the ministry, but theology is not a "professional discipline." If Milbank is right, and I think he is, theology must be part of the curriculum of any university that desires to have the purpose universities profess.

27 Milbank, pp. 45f.

28 Newman makes the distinction between "discovery" and "teaching" in the "Preface" to The Idea of a University, edited, with Introduction and Notes, by Martin Svaglic (New York: Rinehart and Co., 1960), p. XL. One always hesitates to disagree with Newman, but I think he was wrong to make this strict distinction between discovery and teaching. I am well aware that he simply assumed that this was a division of labor and no doubt sometimes it is, but I think all good teachers discover that teaching requires discovery. Aquinas certainly stands as an exemplification of why discovery and teaching cannot be separated.

29 I think the title, The Idea of a University, also often misleads people. They assume that "idea" means "ideal" or "essence," but as Ian Ker makes clear, Newman meant by idea that which grows gradually 
making possible our ability to see the connection between diverse aspects of a reality. Ian Ker, John Henry Newman: A Biography (Oxford: Oxford University Press, 1988), pp. 302f. Newman, therefore, did not think The Idea of a University was recommending an idea that did not exist but he wished might exist. It is extremely important that the idea in The Idea of a University not be ignored. Newman knew the university had a history. That is why it is important to read Newman's Rise and Progress of Universities and Benedictine Essays (Notre Dame: University of Notre Dame, 2001) as a complementary text to The Idea of a University. The university exists for Newman even when there is no institution that bears that name. For example, he observes that in all times there have been universities and they have flourished because of the desire for learning and the need for teachers. If there has been a demand there has been a supply (Rise and Progress of Universities, $\mathrm{p}$. 51). Though universities have often enjoyed the patronage of the rich, the teacher is strong just to the extent what he teaches has intrinsic value and attraction (pp. 164f.). For Newman the university is certainly an idea, but unless real people exist who teach and learn the idea is unfortunately just an "ideal." Moreover, a site must exist for the university to exist (p. 24). Which means Newman understood that the "idea" of the university would take quite different forms at different times and places.

Newman, Idea of a University, p. 81.

L. Gregory Jones criticizes Newman for commending "knowledge for knowledge's sake," then observes that such a view of knowledge is defensible only when such a view is situated with the more comprehensive end constituted by our worship of God (in an unpublished paper, "Do Universities Still Care about Ideas?: Newman's Proposal and its Implications for Christian Higher Education"). I am suggesting, and I think Jones is in agreement, that is exactly what Newman does. The problem occurs when some of Newman's bald statements are abstracted from his theological frame. Jones observes that Newman did not reject teaching courses on professional education, but Newman only thinks such education is not the primary purpose of the university. However, Newman believes such an education is better taught in the university. Even though I think Newman's view of knowledge for its own end can be defended, I think Newman was wrong to separate knowledge and virtue. He argues that philosophy, no matter how enlightened, gives no command over the passions, but surely that is to accept the view that philosophy is no more than a subject, the most important subject to be sure, in the curriculum. That said, however, I think Newman is right to say that "liberal education makes not the 
Christian, not the Catholic, but the gentleman." See Idea of a University, p. 91. In his eloquent reexamination of Newman's The Idea of the University, Jaroslav Pelikan argues that the principle of knowledge as its own end "must be integrated with a larger and more comprehensive set of first principles, which can be summarized under the heading (likewise Aristotelian) of "the intellectual virtues" (The Idea of the University: A Reexamination [New Haven: Yale University Press, 1992], p. 43). Pelikan rightly calls attention to Aristotle, which means, however, the intellectual virtues cannot be separated from the moral virtues. Ian Ker's paper at the University of Prince Edward Island conference (October 1-3, 2004), "Faith, Freedom, and the Academy: The Idea of the University in the $21^{\text {st }}$ Century," quite persuasively argued that what Newman meant by a "gentleman" had little to do with class but rather Newman thought a gentleman is one with a well educated mind. Ker also maintained that Newman thought such a person would or should be a Christian.

Newman, Idea of a University, p. 38.

33 Newman, Idea of a University, p. 103. In his John Henry Newman: A Biography, particularly chapters nine and ten, Ian Ker stresses the importance of understanding what Newman meant by universal as the apprehension of the interconnectedness of the "whole."

34 Those that assume that Newman was a defender of a core curriculum constituted by the "liberal arts" often do not notice that he insisted that "Irish studies" be part of the disciplines taught in the Catholic University of Ireland. In her "Introduction" to Newman's Rise and Progress of Universities and Benedictine Essays (Notre Dame: University of Notre Dame, 2001), Katherine Tillman tells us that Newman "regularly attended" the lectures of Eugene O'Curry who held the Chair of Irish History and Archaeology (p. LXXIII). That Newman attended O'Curry's lectures is not surprising because Newman thought that in the sixth and seventh centuries Ireland saved Christianity. He observes "the Irish, whose brilliancy of genius has sometimes been considered, like the Greek, to augur fickleness and change, have managed to persevere to this day in the science of the saints, long after their ancient rivals have lost the gift of faith."

35 Newman says, "Political economy is the science, I suppose of wealth a science simply lawful and useful, for it is no sin to make money, any more than it is a sin to seek honour; a science at the same time dangerous and leading to the occasions of sin, as is the pursuit of honour too; and in consequence, if studied by itself, and apart from the control of Revealed Truth, sure to conduct a speculator to unchristian conclusions." (Idea of a University, pp. 64f.) Later Newman observes 
that every art is improved by confining the professor of it to a single study, but though the art is advanced by such a concentration, the individual who pursues the discipline "goes back." According to Newman the advantage to the community is in inverse ratio to the person who commits himself to such a concentrated study (pp. 127f.).

36 Gerard Loughlin, "The University Without Question: John Henry Newman and Jacques Derrida on Faith in the University" (Unpublished Paper), pp. 18f. The internal quotes come from The Idea of a University, 1852, Discourse V, pp. 423, 421, 428. Loughlin's reflections on Newman and Derrida were motivated by the closure of the Department of Religious Studies at the University of Newcastle. The Department of Philosophy had been closed some years earlier, occasioning Loughlin's question to the Vice-Chancellor whether you can have a university without a Department of Philosophy. Loughlin reports the ViceChancellor replied that you could have a university without a Department of Religious Studies and the Vice-Chancellor has made the theoretical possibility reality. It would be quite instructive to compare Newman's understanding of the role of philosophy with Alasdair MacIntyre's account in his essay, "Aquinas's Critique of Education: Against His Own Age, Against Ours," in Philosophers on Education: New Historical Perspectives, edited by Amelie Oksenberg Rorty. (London: Routledge, 1998), p. 95-108. MacIntyre, like Newman, argues that there is that of which theology can speak about which philosophy knows nothing and there are types of questions answers to which can only be given by philosophy. But there is also a range of questions about human nature and the ends of life philosophy and theology share. MacIntyre accordingly argues that theology cannot do its work well in what they have to say about human affairs, divine providence, divine law, and redemption and grace without the work of philosophy. So theologians have to become philosophers if they are to speak intelligibly about human powers, reasoning, will and choice and the relationship of human beings to their ultimate good (pp. 98f.). I have criticized MacIntyre for sometimes maintaining a far too rigid distinction between theology and philosophy, but I think he is exactly right about the theologians' need to do philosophy. In his paper on In his paper on Newman's Idea at the University of Prince Edward Island conference, Ian Ker helpfully reminded us that by "philosophy" Newman meant that habit of mind characterized by equitableness, moderation, and wisdom rather than philosophy as a department in the university

Newman, Idea of a University, pp. 31f.

38 Newman, Idea of a University, p. 52. It may be objected that Newman's reference to "public schools" means what he says is not relevant to the 
university. Newman certainly argued that schools and colleges should rightly be concerned with "moral formation" in a manner that distinguished them from the university, but I do not think he is arguing that theology is only relevant to schools and colleges and not the universities. Newman also thinks the "theology" he thinks necessary is natural theology, but he also says on the same page from which the quotation is taken that he has done so only to carry with him those who are not Catholic. He, moreover, suggests that much more must be about "revealed facts and principles" for theology to do its proper work.

39 Newman, Idea of a University, p. 52. Newman claims that by "theology" he means "natural theology" because he wants to "carry along" those who are not Catholics. He observes, however, "that no one can really set himself to master and to teach the doctrine of an intelligent Creator in its fullness, without going on a great deal farther than he at present dreams" (p. 52). Newman seems, therefore, to maintain that natural theology requires the truths of revelation which "furnishes facts to the other sciences, which those sciences, left to themselves, would never reach; and it invalidates apparent facts, which, left to themselves, they would imagine" (p. 54). Newman does not argue that theology can be part of the curriculum only as natural theology, but he rightly assumes "revealed theology" must be part of the curriculum (p. 54). By "fact" I do not think Newman meant that "facts" come uninterpreted, but rather are that which we only know by someone showing us the importance of this or that.

Newman, Idea of a University, pp. 155f.

41 Laughlin, I think, rightly characterizes Newman's views by noting that "the labour of knowledge is divided among the sciences, and when 'certain sciences are away' we have a 'defective apprehension' of the truth. All sciences are needed for the seeking of truth, in the university where it is sought. Thus Newman offers us a view of a unified existence, of creation in relation to creator, which must be studied by us - as particular, limited creatures - through a myriad of inter-related sciences: a truly interdisciplinary labor for the truth. And this common labour includes the co-dependence of theology on other disciplines, through which it learns of its own proper divine subject through their learning of the world which the creator has made and makes to be. On Newman's account, theology does not appear as the 'queen of the sciences', but as the first amongst equals, for the truth which is to be known in theology is the fundamental condition of all knowledge" (pp. 18f.). Newman notes the Church "fears no knowledge, but she purifies all; she represses no element of our nature, but cultivates the whole" ( $p$. 178). 
Newman, Idea of a University, p. 163.

43 Newman observes "that the Church's true policy is not to aim at the exclusion of Literature from Secular Schools, but at her own admission into them. Let her do for Literature in one way what she does for Science in Another; each has its imperfection, and she has her remedy for each. She fears no knowledge, but she purifies all; she represses no element of our nature, but cultivates the whole" (Idea of a University, p. 178).

44 Newman, Idea of a University, p. 50.

45 Newman, Idea of a University, p. 44.

46 Newman, Rise and Progress of Universities, pp. 180-183.

47 Newman, Idea of a University, p. XXXVII.

48 I am, therefore, sympathetic to Gustafson's argument in An Examined Faith: The Grace of Self-Doubt that theology cannot and should not avoid the challenge presented by the knowledges of the university. Gustafson, however, thinks such challenges are more easily located than I believe possible. Gustafson is surely right that any effort to integrate science and theology is futile, but Gustafson seems to think the results of science will always be a challenge to the theologian. I do not assume that some scientific results may be a challenge, but it is the metaphysical presumptions that inform a science that are more likely to be the source of conflict. For example, if physics were thought to show that mechanistic causation "explains" all change, then I think there is a real conflict between theology and physics. Kenneth Miller, for example, quite rightly observes the "chance" that is assumed to be at the heart of a Darwinian account of the world is "not only consistent with the idea of God, it is the only way in which a truly independent physical reality can exist" Finding Darwin's God: A Scientist's Search for Common Ground Between God and Evolution (New York: Harper, 1999), pp. 234f. Miller has the good sense, as a scientist, not to make God part of the metaphysical furniture of the universe. He, therefore, quite rightly argues that "evolution is not rigged" and that his faith in God does not "require one to postulate a God who fixes the game" (p. 238).

49 I am, of course, thinking about the dominance of rational choice methods not only in economics but most of the social sciences. I am not suggesting that there is nothing to be learned from rational choice, but the "method" clearly seems to reproduce the liberal assumptions about human cooperation that should be challenged.

50 Equally crucial is whether a people exist that demand the work of theology be done. I have focused this paper on the university, but as 
important as the university is whether there is an educated public (or church) that not only wants the work of the university to be done, but needs such work. One of the deepest problems confronting the modern university is the loss of such a public. I think few have seen this more clearly than Alasdair MacIntyre who observes, "there is no type of institutional arena in our society in which plain persons - not academic philosophers or academic political theorists - are able to engage together in systematic reasoned debate designed to arrive at a rationally well-founded mind on these matters, a common mind which might then be given political expression. Indeed the dominant forms of organization of contemporary social life militate against the coming into existence of this type of institutional arena. And so do the dominant modes of what passes for political discourse. We do not have the kinds of reading public necessary to sustain practically effective social thought. What we have instead in contemporary society are a set of small-scale academic publics within each of which rational discourse is carried on, but whose discourse is of such a kind as to have no practical effect on the conduct of social life" ("Some Enlightenment Projects Reconsidered," in Questioning Ethics: Contemporary Debates in Philosophy, edited by Richard Kearney and Mark Dooley [London: Routledge, 1999], p. 257). MacIntyre has developed an exemplification of what a learned public might look like in his "The Idea of an Educated Public," in Education and Values: The Richard Peters Lectures, edited by Graham Hudson (London: University of London Institute of Education, 1987). 